\title{
Hyper-homocysteinemia is Not a Main Feature of Juvenile Uncomplicated Type 1 Diabetes
}

\author{
Gian Franco Meloni', Gian Carlo Tonolo², Cecilia Zuppi ${ }^{3}$, Bruno Zappacosta ${ }^{4}$, and \\ Salvatore Musumeci ${ }^{1,5}$ \\ ${ }^{1}$ Department of Pharmacology, Ginecology and Obstetrics, Pediatrics, University of Sassari, Sassari, Italy. \\ 2 Diabetology Unit, Department of Clinica Medica and Patologia Medica, University of Sassari, Sassari, Italy. \\ ${ }^{3}$ Department of Clinical Chemestry, Catholic University, Rome, Italy. \\ ${ }^{4}$ Center for High Technology Research and Education in Biomedical Science, Catholic University, Campobasso, \\ Italy. \\ ${ }^{5}$ Institute of Population Genetics, C.N.R., Alghero, Sassari, Italy.
}

\begin{abstract}
Total plasma homocysteine (tHcy) was measured by high pressure liquid chromatography (HPLC) method in 28 patients (12 females and 16 males) at the onset of type 1 diabetes mellitus (T1DM), 4 females during diabetes ketoacidosis (DKA) and 154 (68 females and 86 males) during follow-up. Serum folate, pyridoxal 5' phosphate (PLP) and Vitamin B12 (Vit B12) were also measured. Plasma tHcy levels were not found significantly different in T1DM patients known to have diabetes (males $9.2 \pm 7.7$ and females $7.0 \pm 2.8 \mu \mathrm{mol} / \mathrm{l}$ ) and in those who were newly diagnosed (males $9.7 \pm 4.8$ and females $7.16 \pm 2.8 \mu \mathrm{mol} / \mathrm{l}$ ) than in healthy controls (males $8.7 \pm 3.5$ and females $7.8 \pm$ $2.55 \mu \mathrm{mol} / \mathrm{l})$. Only a significant difference for sex was observed in known diabetes $(p=$ 0.0281). Serum folate, PLP and Vit B12 were normal $(12.6 \pm 3.6 \mathrm{ng} / \mathrm{ml}, 20.11 \pm 0.8 \mathrm{ng} /$ $\mathrm{ml}$ and $416.7 \pm 41.9 \mathrm{pg} / \mathrm{ml}$ ) in all T1DM patients. Age significantly correlated with plasma tHcy. Only in 4 patients, studied during DKA, plasma tHcy was significantly lower $(2.76 \pm 1.33 \mu \mathrm{mol} / \mathrm{l}, p<0.001)$ than the healthy controls. J Atheroscler Thromb, 2005; 12: 14-19.
\end{abstract}

Key words: Homocysteinemia, Type 1 diabetes, Vascular damage, Microalbuminuria

\section{Introduction}

Homocysteine (Hcy) is an intermediate sulphur-containing amino acid formed during methionine metabolism. Many factors may determine an alteration of the Hcy metabolism, such as low levels of folate, Vitamin B6 (Vit B6) and Vitamin B12 (Vit B12). A strong correlation between plasma Hcy levels and cigarette smoke, large consumption of coffee, obesity, hypertension, diabetes, age and gender has been found (1). Moreover increased plasma Hcy levels seem to be implicated in the atherosclerosis process (2,3). A link between plasma hyper-

Address for correspondence: Salvatore Musumeci, Department of Pediatrics, Viale San Pietro 12, 07100, Sassari, Italy.

E-mail: smusumeci@tiscalinet.it

Received May 7, 2004.

Accepted for publication August 13, 2004.
Hcy and micro and macro-vascular lesions in adult patients with $\operatorname{T1DM}(4,5)$ and in adolescent with type 1 diabetes has been recently reported (6). The link with adolescent type 1 diabetes mellitus (T1DM) is not universally accepted, since difference in dietary intake of folates and Vit B12 (reflected by higher plasma levels) might be a confounding factor (7). It remains to be clarified if hyper-Hcy might be considered a predictor of future micro-macrovascular complications in T1DM or it simply rises, when chronic microvascular or macrovascular complications are already established. One could speculate that if hyper-Hcy is a marker responsible in part, of such chronic complications such as diabetic nephropathy, it should be possible to find plasma hyper-Hcy in a consistent number of uncomplicated T1DM patients, since about $20 \%$ of them develop nephropathy during their life. Since patients with higher albu- 
min excretion rate (AER) show a higher frequency of late kidney complications than those subjects with AER $<20$ mg 24 hours, we think that higher plasma tHcy levels should be found in those subjects with AER > 20 mg 24 hours (8).

The aim of this study is therefore to investigate, in a large sample of Sardinian without complications T1DM patients over a large range of age, the possibility that in a cluster of them plasma hyper-Hcy could be a predictor of macro and micro vascular complications.

\section{Patients and Methods}

A total of 186 patients with T1DM, 84 females and 102 males, with age ranging from 2 to 27 years (median 13 years), with age at onset $\leq 15$ years and without clinical signs of chronic microvascular or macrovascular complications were studied. Twenty-eight were observed at the onset of the disease, 154 were studied during a normal follow-up (diabetes duration ranging from 1 to 21 years), four patients were studied during a diabetes ketoacidosis (DKA) (diabetes duration ranging from 2 to 11 years), but due to the DKA they were not included in the cumulative analysis. All patients were treated with insulin (at least three injections a day). In all patients, hemoglobin A1c (HbA1c), uric acid, serum creatinine, triglycerides, total cholesterol, high density lipoprotein (HDL) and low density lipoprotein (LDL) cholesterol were determined by standard methods. Urine was collected over 24 hours for AER in three different occasions over a period of 6 months. Total plasma homocysteine (tHcy) levels were measured with a high pressure liquid chromatography (HPLC) system and fluorescence detection ( $\lambda$ ex $=385 \mathrm{~nm}, \lambda \mathrm{em}=515 \mathrm{~nm}$ ) (9) at the Department of Clinical Chemistry, Catholic University, Rome, Italy; Serum folate, pyridoxal 5'-phosphate (PLP) and Vit B12 were also determined in all patients with standard methods in the same Department.

One hundred healthy control Sardinian subjects (51 females and 49 males), aged 3 to 29 years (median 12.2), were also studied. Blood samples were collected in the morning after 12 hours of fasting. Mean and standard deviation were calculated for each studied parameter and the differences were evaluated with the Student $T$ test. The correlation indexes and the relative value of $r$ were calculated with SPSS-10 program. $p<0.05$ was considered to be statistically significant.

\section{Results}

Clinical and laboratory findings of the T1DM patients are summarized in Table 1: patients were divided in males and females, if they were studied at the onset of diabetes (newly diagnosed) or during the follow-up (known diabetes). Serum creatinine was below $100 \mu \mathrm{mol} / \mathrm{l}$ in all patients and $\mathrm{HbA1c}$ was higher in newly diagnosed patients In T1DM considered as a whole $(n=186)$, plasma tHcy values $(8.15 \pm 5.99 \mu \mathrm{mol} / \mathrm{l})$ were not statistically significantly different from the controls. In the healthy control subjects, mean plasma tHcy levels were $8.5 \pm 3.2$ $\mu \mathrm{mol} / \mathrm{l}$ and no significant difference was found between females and males $(7.8 \pm 2.55$ and $8.7 \pm 3.5 \mu \mathrm{mol} / \mathrm{l} \mathrm{re}-$ spectively). The distribution curves of plasma tHcy values in the control subjects and in the T1DM patients were comparable (Fig. 1) and only 6 T1DM patients showed plasma tHcy values higher than the maximum values found in controls. Plasma tHcy levels were lower in females than in males, but this difference was significant only in 154 T1DM studied at follow up $(7.0 \pm 2.8$ in females versus $9.17 \pm 7.7$ in males, $p=0.0281$ ). This difference was not significant comparing the newly diagnosed and the known diabetes for sex. In the four patients studied during DKA, tHcy was 3-times lower (2.76 $\pm 1.33 \mu \mathrm{mol} / \mathrm{l})$ than in healthy control and in diabetic patients. In T1DM in a whole (n. 186), a significant correlation between plasma tHcy and age, diabetes duration and serum uric acid was found (Table 2). In the healthy control plasma tHcy correlated with age, but at a lower level of significance $(p \geq 0.01)$. When a multiple linear correlation was performed in T1DM patients only age correlated significantly as an independent variable to tHcy $(p=0.001$ ) (Fig. 2), while diabetes duration and serum uric acid, both highly correlated with age, were not fundamental independent variables for tHcy.

No significant correlation was found between plasma tHcy values and $\mathrm{HbA} 1 \mathrm{c}$, lipid parameters, and microalbuminuria $(r=0.08)$. AER was limited in our known diabetes patients and it was medially $2.5 \pm 4.2 \mathrm{mg} / 24$ hours, below the values of $20 \mathrm{mg} / 24$ hours, which was considered to be discriminator for nephropathy. It was undetectable in newly diagnosed patients, with exception of one male patient ( $10 \mathrm{mg} / 24$ hours). Also when we divided the patients in two groups with $A E R<5 \mathrm{mg} /$ 24 hours and $>5 \mathrm{mg} / 24$ hours, plasma tHcy was not significantly different (median and range 7.9 (1.6-28.4) and 6.3 (1.9-48.3) respectively). In the six T1DM patients (see Fig. 1), who showed plasma tHcy levels above the maximum level found in healthy controls $(20 \mu \mathrm{mol} / \mathrm{l})$, only diabetes duration (9.5 years, range $2-15$ years) was significantly different from the other T1DM patients $(p=$ $0.041)$, besides, of course, plasma tHcy $(31 \pm 11.7 \mu \mathrm{mol} /$ I), while AER was not significantly different $(2.9 \pm 3.3 \mathrm{mg} /$ 24 hours). Serum folate, PLP and Vit B12 were in the normal range $(12.6 \pm 3.6 \mathrm{ng} / \mathrm{ml}, 20.1 \pm 10.8 \mathrm{ng} / \mathrm{ml}$ and $416.7 \pm 41.9 \mathrm{pg} / \mathrm{ml}$ respectively) in all T1DM patients and no correlation between plasma tHcy values and these three parameters was found. 
Table 1. Clinical and laboratory parameters of 182 Sardinian patients with juvenile type 1 diabetes and 100 normal healthy controls of comparable age. Median (range) and mean \pm SD.

\begin{tabular}{|c|c|c|c|c|c|c|}
\hline & \multirow{2}{*}{$\begin{array}{c}\text { Newly diagnosed } \\
\text { (Females) }\end{array}$} & \multirow{2}{*}{$\begin{array}{c}\text { Known diabetes } \\
\text { (Females) }\end{array}$} & \multirow{2}{*}{$\begin{array}{l}\text { Newly diagnosed } \\
\text { (Males) }\end{array}$} & \multirow{2}{*}{$\begin{array}{c}\text { Known diabetes } \\
\text { (Males) }\end{array}$} & \multicolumn{2}{|c|}{ Normal healthy controls } \\
\hline & & & & & (Females) & (Males) \\
\hline Number & 12 & 68 & 16 & 86 & 51 & 49 \\
\hline Age (years) & $12(3-14)$ & $13(5-26)$ & $10(4-14)$ & $14(2-27)$ & $12(3-29)$ & $12(3-29)$ \\
\hline $\begin{array}{l}\text { Diabetes duration } \\
\text { (years) }\end{array}$ & 0 & $4(1-21)$ & 0 & $6(1-19)$ & 0 & 0 \\
\hline $\mathrm{HbA1C}(\%)$ & $11.8 \pm 2.3^{* *}$ & $7.9 \pm 2.1$ & $11.2 \pm 2.5^{* *}$ & $7.7 \pm 1.7$ & $3.3 \pm 1.3$ & $3.3 \pm 1.4$ \\
\hline Uric acid (mg/dl) & $3.4 \pm 2.3$ & $2.8 \pm 0.9$ & $4.1 \pm 3.1$ & $3.4 \pm 1.2$ & $3.5 \pm 1.9$ & $3.7 \pm 1.7$ \\
\hline $\begin{array}{l}\text { Serum creatinine } \\
(\mu \mathrm{mol} / \mathrm{l})\end{array}$ & $70.5 \pm 12.2$ & $69.9 \pm 11.4$ & $71.7 \pm 13.2$ & $69.7 \pm 12.3$ & $68.4 \pm 10.6$ & $69.6 \pm 11.5$ \\
\hline $\begin{array}{l}\text { Total cholesterol } \\
(\mu \mathrm{mol} / \mathrm{l})\end{array}$ & $186.4 \pm 35.5$ & $176.5 \pm 36.9$ & $162.2 \pm 22.0$ & $170.9 \pm 30.2$ & $165.3 \pm 32.3$ & $176 \pm 64.4$ \\
\hline $\begin{array}{l}\text { Triglycerides } \\
(\mathrm{mg} / \mathrm{dl})\end{array}$ & $109.9 \pm 98.8$ & $72.8 \pm 49.0$ & $78.7 \pm 36.8$ & $82.7 \pm 44.8$ & $93.7 \pm 8.6$ & $95.7 \pm 9.4$ \\
\hline $\begin{array}{l}\text { HDL-cholesterol } \\
\text { (mg/dl) }\end{array}$ & $61.2 \pm 38.1$ & $65.8 \pm 22.5$ & $61.2 \pm 16.0$ & $59.5 \pm 11.3$ & $53.3 \pm 20.3$ & $54.7 \pm 18.3$ \\
\hline $\begin{array}{l}\text { LDL-cholesterol } \\
\text { (mg/dl) }\end{array}$ & $97.3 \pm 36.1$ & $92.4 \pm 30.9$ & $93.4 \pm 24.2$ & $94.6 \pm 25.0$ & $91.6 \pm 25.7$ & $92.5 \pm 23.3$ \\
\hline $\begin{array}{l}\text { Microalbuminuria } \\
\text { (mg/24 hours) }\end{array}$ & undetectable & $2.2 \pm 4.0$ & $0(0-10) * * *$ & $2.7 \pm 4.4$ & undetectable & undetectable \\
\hline THcy ( $\mu \mathrm{mol} / \mathrm{l})$ & $7.2 \pm 3.6$ & $7.0 \pm 2.8^{*}$ & $9.7 \pm 4.8$ & $9.17 \pm 7.7$ & $7.8 \pm 2.5$ & $8.7 \pm 3.5$ \\
\hline $\begin{array}{l}\text { Serum folate } \\
(\mathrm{ng} / \mathrm{ml})\end{array}$ & $12.3 \pm 2.9$ & $13.2 \pm 3.2$ & $11.6 \pm 2.6$ & $12.3 \pm 3.0$ & $12.3 \pm 3.1$ & $12.6 \pm 3.6$ \\
\hline PNP (ng/ml) & $20.3 \pm 9.4$ & $21.4 \pm 10.1$ & $19.9 \pm 9.7$ & $20.9 \pm 10.2$ & $20.3 \pm 10.2$ & $21.4 \pm 10.4$ \\
\hline Vit B12 (pg/ml) & $400.1 \pm 2.3$ & $398 \pm 38.9$ & $410 \pm 41.4$ & $403 \pm 39.7$ & $410 \pm 40.2$ & $416.7 \pm 41.9$ \\
\hline
\end{tabular}

Females vs Males $* p=0.029$, Newly diagnosed $v s$ known diabetes, $* * p<0.001$

*** Only in one newly diagnosed patient microalbuminuria was $10 \mathrm{mg} / 24$ hours.

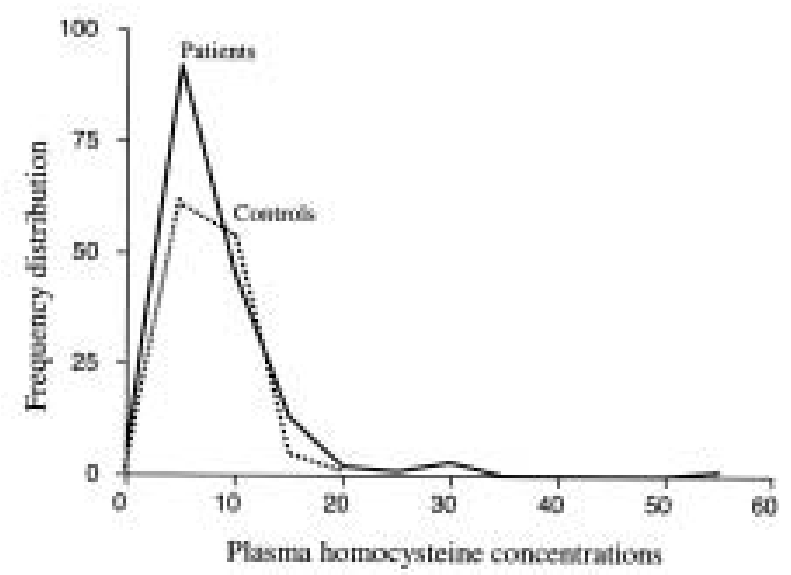

Fig. 1. Plasma tHcy distribution in T1DM patients and in normal healthy controls.
Table 2. Linear correlation between tHcy (as dependent variable) and the other considered independent variables.

\begin{tabular}{lcc}
\hline & $R$ value & $P$ value \\
\hline Age & 0.372 & $<0.001$ \\
Diabetes duration & 0.253 & 0.0015 \\
HbA1c & 0.098 & $\mathrm{NS}$ \\
Serum uric acid & 0.278 & 0.005 \\
Serum creatinine & 0.132 & $\mathrm{NS}$ \\
Cholesterol & 0.092 & $\mathrm{NS}$ \\
Triglycerides & 0.052 & $\mathrm{NS}$ \\
AER $<5$ mg/dl & 0.148 & $\mathrm{NS}$ \\
AER $>5$ mg/dl & 0.099 & $\mathrm{NS}$ \\
AER (only males) & 0.152 & $\mathrm{NS}$ \\
AER (only females) & 0.130 & $\mathrm{NS}$ \\
Serum folate & 0.125 & $\mathrm{NS}$ \\
PNP & 0.110 & $\mathrm{NS}$ \\
Vit B12 & 0.124 & $\mathrm{NS}$ \\
\hline
\end{tabular}

HbA1c: glycated hemoglobin, AER: Albumin excretion rate 


\section{Discussion}

Typical microvascular complications of diabetes are retinopathy, nephropathy and neuropathy, which seem to be related to increase in glucose flux through polyol pathway. The altered polyol metabolism is responsible of increased protein glycation, depletion of myoinositol and reduction of the ATP-dependent proton-potassium pump $\mathrm{Na}^{+}, \mathrm{K}(+)$-ATPase (10). Moreover the increased production of transforming growth factor beta(1) (TGF- $\beta 1$ ) can cause vascular alterations (such as increased blood flow and increased vascular permeability, abnormal viscosity, dysfunctions of platelets and endothelial cells and changes in oxidative stress), which might interact with a genetic predisposition, thus leading to these typical complications of diabetes (11). These alterations finally determine endothelial tissue damage and consequent occlusive angiopathy (12). The exact role of each one of these components is not perfectly known, but an adequate insulin therapy is usually able to normalize glucose level and to slow down the progression of vascular damage, in most but not in all of the patients.

Plasma hyper-Hcy level has been considered an important parameter connected to endothelial lesions in adult diabetics. In fact diabetic patients with poor metabolic control, early age onset and folate deficiency show elevated plasma Hcy levels (13). A synergistic action between Hcy and AGE (Advanced Glycation End Products) seems to increase the release of soluble thrombomodulin (STM), a marker of endothelial cells dam- age, in "in vitro" experiments in cells of human umbilical vein (14). This suggests that thcy could represent the conjunction between the metabolic alteration of diabetes and the endothelial vascular damage.

In adult diabetic patients, a direct relation between micro and macro-albuminuria $(15,16)$, glomerular filtration rate (17), diabetic nephropathy (4), cardiovascular disease (5) and plasma Hcy levels has been reported. The same can not be supported by other studies $(18,19)$, in T1DM patients, where the levels of plasma tHcy were found in the normal range for controls mached for age and sex. Other authors found a marked increase of plasma tHcy concentration using methionine loading test in young diabetic patients with $>70 \mu \mathrm{g} / \mathrm{min}$ of microalbuminuria (fasting values: $14.7 \pm 5.6 \mu \mathrm{mol} / \mathrm{l}$; after methionine load: $34.2 \pm 12.6 \mu \mathrm{mol} / \mathrm{l})$ and in patients with proliferative retinopathy (fasting values $15.1 \pm 5.0 \mu \mathrm{mol} /$ I; after methionine load $36.8 \pm 12.5 \mu \mathrm{mol} / \mathrm{l})$, which suggest an unbalanced methionine metabolism when the diabetes dates of long time (5). Thus an increased plasma tHcy level might contribute to an increased morbidity from cardiovascular disease in adolescent and young adults with diabetic retinopathy and nephropathy. Recently Jager et al 2001 (20) reported that the increase of plasma tHcy precedes the appearance of microalbuminuria. In fact an increase of $5 \mu \mathrm{mol} / \mathrm{l}$ over the normal value for age was associated with an increased risk of developing microalbuminuria. One of the aims of our study was to detect possible differences in plasma tHcy levels relative to the AER, in order to evaluate the possibility that

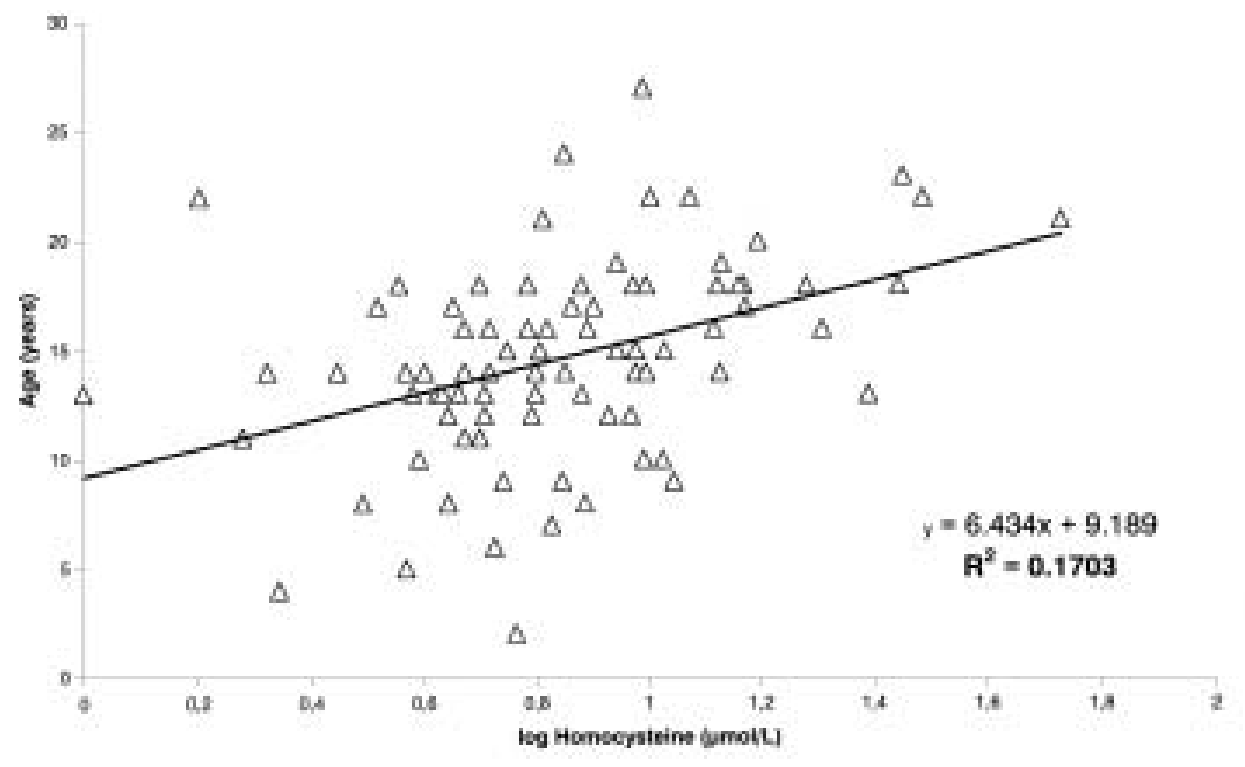

Fig. 2. Correlation between tHcy and age in 154 patients with known diabetes. 
plasma tHcy values might represent a marker of possible evolution to diabetic nephropathy. We were not able to find any correlation between tHcy and urinary albumin excretion. Also the 6 patients with the highest tHcy levels $(>20)$ did not show higher urinary albumin excretion rate than the other patients, although diabetes duration was significantly longer. In summary, our young T1DM patients do not show abnormal values of tHcy within an AER values $\leq 10 \mathrm{mg} / 24$ hours. This may be due in part to an accurate insulin therapy and a free diet with regular folate intake. The only significant difference was found for the sex, with tHcy values being lower in females than in males, as previously reported (21). Other studies (22) show evidence that in patients with severe retinopathy, the most elevated levels of plasma tHyc are confined in those with serum creatinine level $>100 \mu \mathrm{mol} / \mathrm{l}$.

The low level of plasma tHcy in the four patients with DKA is not usual in T1DM. Due to the low number of subjects, this phenomenon is difficult to evaluate, but it may be considered a consequence of severe derangement of glucose, lipid and electrolytes homeostasis, which may be rapidly corrected by insulin and glucose treatment.

In conclusion our results confirm recent data, which report normal level of plasma Hcy in T1DM patients (23). In any case, considering that a trend to higher values of plasma tHcy with the age $\left(r^{2}=0.17, p<0.001\right)$ is more significant in young T1DM than in our control group of the same age, we suggest in such a metabolic situation, the measure of plasma tHcy levels in order to prevent the endothelial damage.

In particular patients with atypical anaemia, as well as in an undernutrition state and with an initial increase of serum creatinine levels ( $>100 \mathrm{umol} / \mathrm{l}$ ) plasma tHcy should be monitored, since serum folate concentration must be maintained elevated by adding folate to the diet, while the intake of proteins especially a high content of methionine must be reduced.

\section{References:}

(1) Targher G, Bertolini L, Zenari L, Cacciatori V, Buggero M, Faccini G, and Zoppini G: Cigarette smoking and total plasma homocysteine levels in young adults with type I diabetes. Diabetes Care, 23: $524-528,2000$

( 2 ) Domagala TB, Undas A, Libura M, and Szczeklik A: Pathogenesis of vascular disease in hyperhomocysteinaemia. J. Cardiovasc Risk, 5: 239-247, 1998

( 3 ) Saw SM: Homocysteine and atherosclerotic disease: the epidemiologic evidence. Ann Acad Med Singapore, 28: 565-568, 1999

(4) Buysschaert M, Dramais AS, Wallemacq PE, and Hermans MP: Hyper-homocysteinemia in type 2 dia- betes: relationship to macroangiopathy, nephropathy and insulin resistence. Diabetes Care, 23: 18161822,2000

( 5 ) Parving HH, Nielsen FS, Bang LE, Smidt UM, Svendsen TL, Chen JW, Gall MA, and Rossing P: Macro-microangiopathy and endothelial dysfunction in NIDDM patients with and without diabetic nephropathy. Diabetologia, 39: 1590-1597, 1996

(6) Chiarelli F, Pomilio M, Mohn A, Tumini S, Vanelli M, Morgese G, Spagnoli A, and Verzotti A: Homocysteine levels during fasting and after methionine loading in adolescent diabetic retinopathy and nephropathy. J Pediatr, 137: 386-392, 2000

( 7 ) Wiltshire E, Thomas DW, Baghurst P, and Couper $\mathrm{J}$ : Reduced total plasma homocysteine in children and adolescent with type 1 diabetes. J Pediatric, 138: 888-893, 2001

( 8 ) Olsen BS, Sjolie AK, Hougaard P, Johannesen J, Marinelli K, Jacobsen BB, Mortensen HB and Danish Study Group of Diabetes in Childhood: The significance of the prepubertal diabetes duration for the development of retinopathy and nephropathy in patients with type 1 diabetes. Diabetes Complications, 18:160-164, 2001

( 9 ) Vester B and Rasmussen K: High Performance Liquid Chromatography method for rapid and accurate determination of homocysteine in plasma and serum. Eur J Clin Chem, 29: 549-554, 1991

(10) Vague $P$, Coste TC, Jannot MF, Raccah D, and Tsimaratos M: C-peptide, $\mathrm{Na}^{+}, \mathrm{K}(+)$-ATPase, and diabetes. Exp Diabesity Res, 5: 37-50, 2004

(11) Flores L, Naf S, Hernaez R, Conget I, Gomis R, and Esmatjes E: Transforming growth factor beta at clinical onset of Type 1 diabetes mellitus. A pilot study. Diabet Med, 21: 818-822, 2004

(12) Dahl-Jorgensen K: Diabetic microangiopathy. Acta Pediatr Suppl, 425: 31-34, 1998

(13) Hultberg B, Agardh CD, Agardh E, and LovestamAdrian M: Poor metabolic control, early age at onset and marginal folate deficiency are associated with increasing levels of plasma homocysteine in insulin-dependent diabetes mellitus. A five-year follow-up study. Scand J Clin Lab Invest, 57: 595600, 1997

(14) Hofmann MA, Kohl B, Zumbach MS, Borcea V, Bierhaus A, Henkels M, Amiral J, Fiehn W, Ziegler R, Wahl P, and Nawroth PP: Hyper-homocyst(e)inemia and endothelial dysfunction in IDDM. Diabetes Care, 20: 1880-1886, 1997

(15) Chico A, Perez A, Cordoba A, Arcelus R, Carreras G, de Leiva A, Gonzales-Sastre F, and Blanco-Vaca F: Plasma homocysteine is related to albumin excretion rate in patients with diabetes mellitus: a new link between diabetic nephropathy and cardiovascular diseases? Diabetologia, 41: 684-693, 1998, 
(16) Robinson K and Dennis VW: From microalbuminuria to hyper-homocysteinemia. Kidney Int, 54: 281-282, 1998

(17) Wollesen F, Brattstrom L, Refsum H, Ueland PM, Berglund L, and Berne C: Total plasma homocysteine and cysteine in relation to glomerular filtration rate in diabetes mellitus. Kidney Int , 55: 1028-1035, 1999

(18) Salardi S, Cacciari E, Sassi S, Grossi G, Mainetti B, Dalla Casa C, Pirazzoli P, Cicognani A, and Gualandi S: Homocysteinemia, serum folate and vitamin B12 in very young patients with diabetes mellitus type 1. J Pediatr Endocrinol Metab, 13: 1621-1627, 2000

(19) Vaccaro O, Perna AF, Mancini FP, lovine C, Cuomo $V$, Sacco M, Tufano A, Rivellese AA, Ingrosso D, and Riccardi G: Plasma homocysteine and microvascular complications in type 1 diabetes. Nutr Metab Cardiovasc Dis, 10: 297-304, 2000

(20) Jager A, Kostense PJ, Nijpels G, Dekker JM, Heine
RJ, Bouter L, Donker AJ, and Stehouwer CD: Serum homocysteine levels are associated with the development of (micro) albuminuria: the Hoorn study. Arteroscler Thromb Vasc Biol, 21: 74-81, 2001

(21) Matteucci E, Rossi L, Mariani S, Fagnani F, Quilici S, Cinapri V, and Giampietro O: Blood levels of total homocysteine in patients with type 1 diabetes (with no complications, diabetic nephropathy and/ or retinopathy) and in their non-diabetic relatives. Nutr Metab Cardiovasc Dis, 12: 184-189, 2002

(22) Agardh E, Hultberg B, and Agardh CD: Severe retinopathy in type I diabetic patients is not related to the level of plasma homocysteine. Scand J Clin Lab Invest, 60: 169-174, 2000

(23) Pavia C, Ferrer I, Vallis C, Artuch R, Colome' C, and Vilaseca MA: Total homocysteine in patients with type 1 diabetes. Diabetes Care, 23:84-87, 2000 